\title{
Urban Governance and the Politics of Climate Change
}

\section{Introduction}

International development policy in 2015 delivered a consolidated view of cities and urban areas as strategic arenas for climate change action. The 2015 Sustainable Development Goals (with the inclusion for the first time of an explicit urban goal) have emerged linked to a radical change towards a pro-urban policy consensus in sustainable development (Barnett and Parnell 2016). The 2015 Paris Agreement for Climate Action underscores the importance of subnational levels of implementation. Alongside the Agreement, Anne Hidalgo, Mayor of Paris, and Ignazio Marino, Mayor of Rome, hosted the Climate Summit for Local Leaders, a series of side events under the auspices of the Secretary General's Special Envoy for Cities and Climate Change, former New York City mayor Mike Bloomberg, which emphasized urban areas as innovation testing zones and showcased climate action at the local level. The underlying assumption in these initiatives is that cities and urban areas can help bridge the gap between the aggregate national intended contributions agreed in Paris, and the actual requirements of emissions reductions needed to keep temperature changes under 1.5 degrees. The United Nations machinery is now working towards a new urban agenda, a global agenda that addresses the challenges and opportunities of urbanization in a consultation process that will culminate in Quito, in October 2016, at the III United Nations Conference on Housing and Sustainable Urban Development (UN-Habitat, 2014). The most salient feature of debates surrounding the new urban agenda is a definitive abandonment of perspectives that cast urbanization as a challenge to be controlled in favor of those which emphasize the opportunities for living sustainably in an increasingly urban future (Parnell 2016).

Today, transitions to sustainability emerge inevitably related to the possibilities opened for action in urban areas (Bulkeley et al. 2010, Frantzeskaki et al. 2016). Simultaneously, this interest in urban areas casts a new light on global environmental politics, as Solecki and Leichenko (2006) predicted. In the 
international policy arena, climate change has most often been presented as a global problem requiring global solutions (Bulkeley 2013, Bulkeley and Newell 2015). For example, climate change action was delinked from the emphasis on local action that followed sustainability agendas from the 1992 Rio Declaration on Sustainable Development to the Local Agenda 21, despite international efforts to coordinate what was often perceived as two separated realms of action (e.g. Gebre-Egziabher 2004). The spectacular failure of international negotiations in the 2009 COP15 in Copenhagen has often been regarded as an inflexion point in climate politics. Copenhagen marked a radical shift towards voluntary commitments for climate action in nation states and away from multilateralism. Social movements' abandonment of the meeting made visible the disconnection between public attitudes to climate change and the seemingly cynical positions of negotiators. Yet, Copenhagen was also a success because for the first time, the COP showcased the possibilities for action outside the international climate regime, for example, in cities (Hoffmann 2011, Jones 2012). A series of high profile international reports on cities and climate change followed, all emphasizing the possibilities opened up in urban areas to mitigate climate change and adapt to climate changing futures (World Bank, 2011; UN-Habitat, 2011; IPCC, 2014).

The combination of voluntary approaches to climate change policy and a growing interest in local action has supported a politics of climate change where multiple forms of governance, rather than a regulatory understanding of governing, play a fundamental role (Newell et al. 2012). Governance relates to mechanisms directed towards the coordination of multiple forms of state and non-state action (Rosenau 2000). In this vein, governance implies a recognition of the multiple actors who intervene in the purposive steering of society, towards low carbon, resilient or sustainable objectives (Newell et al. 2012, Okereke et al. 2009). For debates on cities and climate change, this means, first, a recognition of the role of local governments alongside other forms of state-control; and second, a turn of attention towards the multiple actors that intervene directly or through hybrid arrangements in urban governance, including 
the business sector, public-private partnerships, civil society organizations and community groups, and other diverse networks of actors who routinely change urban trajectories. Their actions, however, are hardly circumscribed to arbitrarily-defined administrative boundaries of cities: while reshaping metropolitan areas and their hinterland, efforts to govern climate change in cities are also creating new forms of transnational governance (Bulkeley et al. 2014a).

While actions to govern climate change in cities can be found in cities all over the work, regardless of their geographical location and state of development, they emerge associated with the specific problematics that shape the context of implementation. In African cities, for example, action to adapt to climate change and to deliver cleaner energy comes associated with an interest on urban health (Smit and Parnell 2012). What is common everywhere is the need to address the political and governance matters associated with a tremendous socio-ecological and technological transformation (Simon and Leck 2015). While urban areas open indeed numerous opportunities to address climate change, they are also sites of political struggle where the politics of climate change become manifest.

The aim of this review if to evaluate both how climate change politics have led to deep changes in urban governance, and in turn, how new attempts to govern climate change in urban areas is further reconfiguring global environmental politics. For the purposes of this review, governance is understood as a broad concept that relates to intentional actions or interventions to address a specific problem, in this case, climate change. Governance represents a recognition of the multiple actors that perform acts of governing, rather than a move away from the State as the sole source of authority. The review engages with two complementary, but also somehow opposed notions of environmental governance. The first perspective engages with governance as a process resulting from specific attempts to mobilize resources and actors to address climate change. Taking a normative stance that assumes a need to align efforts to address climate change challenges, the notion of governance as a process raises question about the means to improve existing forms of governance. The second perspective engages with 
governance as a means to build authority and support actors' attempts to gain control over different realms of urban life. Taking a critical perspective that questions how the politics of climate change reshape environmental battlefields, the notion of governance as a means of control directs attention to the political struggles that emerge as a result of actions to address climate change.

These two distinct notions of governance structure the argument presented in this review. While from a normative point of view urban areas offer grounds for hope about possible transformations towards low carbon, climate resilience futures, a critical perspective maps a political environment in which climate change has already refashioned the possibilities and consequences of climate-oriented urban development. Both perspectives offer insights into how climate change imperatives are shaping urban governance as well as how actions in urban areas shape global climate politics (key themes are summarized in Table 1). The review engages first with the normative perspective looking first into the processes of institutionalization of climate change action; and then, into the organization of cities into networks and other structures of standing in global climate politics. Then, the argument moves into the critical perspective, to examine first the way climate change discourse has generated new forms of urban governance; and then, to look into climate change politics has consolidated forms of experimental governance as the dominant means to deliver sustainable futures.

\begin{tabular}{|l|l|l|}
\hline \multicolumn{2}{|l|}{ Table 1: Research themes emerging in relation to two alternative views on urban governance } \\
\hline & Responses to climate change in & Urban governance reconfigures \\
& urban areas & climate change politics \\
\hline whereby decisions are made & the institutionalization of & global environmental \\
and implemented. & climate action & governance \\
(Section 1) & & \\
\hline
\end{tabular}




\begin{tabular}{|l|l|l|}
\hline Governance as a means to gain & The discursive production of & The rise of experimentation in \\
control and authority & climate politics at the local level & global climate politics \\
(Section 2) & & \\
\hline
\end{tabular}




\section{Governance as a process whereby decisions are made and}

\section{implemented.}

A key aspiration of the New Urban Agenda is to harness the role of urban areas as a 'source of solutions' for sustainability and resilience, with a paradigm shift to change the "prevailing perception of cities as a significant source of negative ecological impacts" (Bureau of the Preparatory Committee 2016). This is an example of how urban governance discussions are intrinsically linked to debates about responsibilities for climate change action and analyses of actors' motivations to participate in acts of governing. Accepting climate change action as an imperative, the question raised is how to improve urban governance processes to address it. Initial discussions on political leadership, transfer of resources and capacity building have evolved into analyses of the institutional conditions that enable effective climate action. The political question emerges in relation to management of governance institutions who have both the motivations and capacities to deliver climate action. On the other hand, cities become implicated in new forms of urban governance that have broader expression in the global arena. Network governance has consolidated as the key mechanisms whereby cities make visible their influence on transnational climate change politics.

\subsection{Cities, climate action and international development discourses}

How to prioritize different areas of intervention is a central question for the governance of climate change in urban areas. The division between climate change adaptation and mitigation, and the potential conflicts that can emerge between the two, has shaped debates about what kind of action is most appropriate (Laukkonen et al. 2009). While trade-offs between mitigation and adaptation exist, thinking about local interventions offers opportunities for resolving them (Moser 2012). 
Adaptation has most often been framed as a local issue. Urban climate change hazards are not only increasing in severity and frequency, but also, they are likely to have a profound impact in a wide range of urban infrastructures, services, the built environment, and supporting ecosystems (Revi et al. 2014). The impacts of maladaptation may last decades (Fatti and Patel 2013). Over the last two decades, empirical research has consistently emphasized the close relationship between poverty, urban inequality, and the vulnerability of urban populations to climate change impacts (e.g. O'Brien and Leichenko 2000, Douglas et al. 2008, Banks et al. 2011, Satterthwaite 2007). The vulnerability of the urban poor is not only dependent on their exposure to climate-change related hazards, but also on the structural conditions that reproduce poverty, such as economic inequality, lack of political representation, deficient access to services, and diminished life opportunities (e.g. Pelling 2010, Pelling and Manuel-Navarrete 2011, Satterthwaite 2007, Dodman et al. 2012, Castán Broto et al. 2013).

There is thus a wide agreement that urban governance efforts should be directed towards pro-poor forms of adaptation that support the urban poor's assets and that link local development through adaptation planning, especially in programs for upgrading housing and services (Moser and Satterthwaite 2010, Stein and Moser 2014). This argument is by now relatively uncontroversial, being recognized in the experiences of different cities around the world (e.g. Bartlett and Satterthwaite 2016), in the latest reports of the Intergovernmental Panel for Climate Change (Revi et al. 2014) and in policy guidance from international organizations such as the World Bank. For example, the Mayor's Task Force on Climate Change, Disaster Risk and the Urban Poor, launched at the Mayor's Summit in Copenhagen, 2009 and led by the World Bank, has argued for climate change adaptation investments that recognize the position of the urban poor 'at the front line' (Baker 2012). Bartlett and Satterthwaite's (2016) book 'Cities on a Finite Planet' delivers a summary of arguments in the field, with nine case studies of local experiences in climate change adaptation which demonstrate the potential to deliver interventions that work for the urban poor. 
Many such interventions build, more or less explicitly, on discourses of resilience already prevalent in disaster risk reduction agendas (Adelekan et al. 2015). Resilience perspectives highlight how people's capacities to cope with disasters relate to systemic challenges and feedback loops that simultaneously exacerbate poverty and vulnerability (e.g. Wamsler and Brink 2014, Seeliger and Turok 2014). Resilience emphasizes the coevolution between urban practices and ecosystems (McPhearson et al. 2015). It turns attention away from specific technical and spatial planning measures towards facilitating processes of adaptive governance which enable institutional change in rapidly changing environments (Boyd and Folke 2011). Resilience thinking has, however, been challenged for promoting an incremental approach to adaptation that does not fully recognize the structural drivers of vulnerability and their dependence on the dominant structures of capitalism (Pelling 2010, Pelling and Manuel-Navarrete 2011).

Pelling's (2010) book 'Adaptation to Climate Change' presents a framework of adaptation practices that distinguishes between practices of resilience that do not challenge underlying drivers of vulnerability, transition practices that focus on institutional change, and transformative practices that attempt to question the underlying structures, values and assumptions embedded in global political economy structures. For example, political changes towards democracy in South Africa and Brazil may have a transformative impact in water provision systems, although these impacts may take decades to materialize (Hordijk et al. 2014). This critique, however, overlooks the emphasis on institutional change already embedded in resilience thinking (Boyd and Folke 2011, Boyd and Ghosh 2013). Indeed, building resilience is most often considered as synonymous of supporting radical political changes (Bahadur and Tanner 2014) alongside broader paradigm changes that enable more inclusive means of knowledge production (Ensor et al. 2014). Nevertheless, the overall lesson remains: effective adaptation planning in urban areas is akin to a revolution in urban governance that addresses the political, economic and social determinants of poverty and climate change vulnerability. In practice, efforts to integrate adaptation with municipal service provision and disaster risk management services have dominated (e.g. Wamsler 
2015, Howes et al. 2015). The prevalence of economic discourses of urban development misdirects adaptation planning away from transformative forms of change (Boyd et al. 2014). Under a frame of urgency and the need for effective measures, adaptation planning is too often associated with unjust forms of development that either affect the urban poor directly (acts of commission) or prioritize the interests of urban elites (acts of omission) at the expense of actions that address directly the most urgent vulnerabilities affecting the urban poor (Anguelovski et al. 2016).

Mitigation, however, has most often been framed as a global issue (Laukkonen et al. 2009). However, as the scale of the material changes required has become evident, mitigation has become more closely associated to climate justice agendas visible at the local level (Seyfang and Haxeltine 2012, Sovacool 2011). This argument is however seen with suspicion in developing countries because the global politics of climate change are reconfiguring the international aid flows, and hence, aid may be perceived as linked to a Western-led climate mitigation agenda. Nevertheless, mitigation actions are common worldwide, and often they are explicitly linked to environmental and social justice agendas (Castán Broto and Bulkeley 2013, Bulkeley et al. 2013). Yet, pioneering experiences in cities have demonstrated the crucial importance of local sustainability initiatives to deliver mitigation action (Bulkeley and Betsill 2005a, Betsill and Bulkeley 2007).

Unfortunately, a perspective of cities as 'parasites' that degrade surrounding environmental resources has been too prevalent in international development discourses. Lack of data disaggregation leads to analyses which are largely blind to the geographical patterns of environmental degradation, and the gross inequalities that shape such patterns. For example, the attribution of over three quarters of global carbon emissions to cities and urban areas provides a strong rationale for mitigation action targeting the provision of urban infrastructure, specially energy services (e.g. Sharifi and Yamagata 2015). This manner of accounting obscures key aspects such as the differentiation of emissions within cities, the urban-rural linkages that characterize land transformations, and the inaccuracies inherent to carbon 
accounting (Dodman 2009, Satterthwaite 2008, Hoornweg et al. 2011). Simultaneously, the relationship between urbanization and environmental (or land) transformation processes is not fully understood (Seto et al. 2010). From a governance perspective, current patterns of urbanization do not match administrative boundaries and existing governance structures. Spatially, local authorities may have to deal with the challenges of suburbanization (Knuth 2010), metropolitanisation (Padukone 2012), or subserviced development at the peri-urban interface (Simon 2008), further challenging established methods of accounting and mitigation planning.

An alternative approach has been to look into the city to harness opportunities for climate change which may build on existing experiences, but also challenge the status quo because it questions the material basis of existing institutions (Rutherford and Coutard 2014, Bulkeley et al. 2014b). Infrastructure investments, for example, are a means to link mitigation and adaptation objectives (Martin and Rice 2014). In the context of development, clean energy infrastructures, such as clean cookstoves programs, may address directly structural drivers of poverty and vulnerability (Simon et al. 2012). The discourse of cities as sites for opportunity has been powerful enough to reshape global discourses of climate action (see section 2.3.) but, in practice, progress in climate change objectives has not met expectations (Azevedo et al. 2013, Bulkeley 2010). Shifting policy priorities, lack of awareness, and the difficulty to translate policy into concrete action often limits the possibilities to achieve lasting sustainability impacts (Bache et al. 2015, Radzi 2015). At the global level, the conflict between prioritizing resources for mitigation or adaptation remains unsolved and confounded by the multiple impacts, co-benefits and unintended consequences of different actions. Research has turned to understand how local governments can address this conundrum through the institutionalization of climate change action in urban governance. 


\subsection{Climate change institutionalization and urban governance}

While international negotiations have often focused on discussions about the economics of climate change action and agreements on financing mechanisms, at the local level questions emerge about the lack of local governments' competence and capacity, and how climate change issues can be addressed alongside backlogs in infrastructure provision and services, particularly in informal or sub-serviced settlements (Baker 2012, Dodman et al. 2012, Satterthwaite 2007). An initial step in this literature has been to analyze in-depth case studies, mostly from the global north, to examine the institutional factors that enable effective climate change action. A useful analytical device has been to relate such factors with drivers and motivations for action, in an attempt to find routes towards improving local capacities for climate change action. For example, institutional analysis of experiences of early adopters of adaptation planning has led to an analytical differentiation between exogenous drivers of action (from external shocks to the agendas of the international climate regime) and endogenous drivers (from actors' motivations to their capacity to take advantage of the context of action) (Carmin et al. 2012, Anguelovski and Carmin 2011). Table 1 uses this analytical differentiation to provide an illustration of the literature on institutional drivers of climate change action in urban areas. 


\begin{tabular}{|c|c|c|}
\hline & Exogenous drivers & Endogenous drivers \\
\hline $\begin{array}{l}\text { Common } \\
\text { drivers }\end{array}$ & $\begin{array}{l}\text { National political context (Dodman } \\
\text { and Mitlin 2015) } \\
\text { City networks and climate change } \\
\text { diplomacy (see section 2.3) } \\
\text { Lessons from other cities (Solecki } \\
\text { and Leichenko 2006) } \\
\text { Public opinion and political support } \\
\text { for climate action (Finnis et al. } \\
\text { 2015) } \\
\text { Possibility to intervene at city-wide } \\
\text { scales (Hallegatte and Corfee- } \\
\text { Morlot 2011) } \\
\text { Availability of data and } \\
\text { methodological uncertainties (Pitt } \\
\text { and Randolph 2009) }\end{array}$ & $\begin{array}{l}\text { Political leadership (Sanchez-Rodriguez } \\
\text { 2009) } \\
\text { Collaboration and coordination (Jones 2013) } \\
\text { Institutionalisation and sectoral integration } \\
\text { (Burch 2010, Corfee-Morlot et al. 2011, } \\
\text { Birkmann et al. 2010, Li 2011) } \\
\text { Political culture (Francesch-Huidobro 2012) } \\
\text { Possibilities to link-in co-benefits (Sharma } \\
\text { and Tomar 2010, Archer et al. 2014) } \\
\text { Partnerships with local actors and scientists } \\
\text { (Corburn 2009, Corfee-Morlot et al. 2011, } \\
\text { Pasquini and Shearing 2014) } \\
\text { Social and institutional capacity (Altenburg } \\
\text { 2012) }\end{array}$ \\
\hline $\begin{array}{l}\text { Drivers specific } \\
\text { to mitigation }\end{array}$ & $\begin{array}{l}\text { Market dynamics (Azevedo et al. } \\
\text { 2013) } \\
\text { Pressure form international } \\
\text { negotiations (Newell et al. 2012) }\end{array}$ & $\begin{array}{l}\text { Integration of environmental policy and } \\
\text { planning (Barbour and Deakin 2012) } \\
\text { Regulatory frameworks (Cidell and Cope } \\
\text { 2014) }\end{array}$ \\
\hline $\begin{array}{l}\text { Drivers specific } \\
\text { to adaptation }\end{array}$ & $\begin{array}{l}\text { Previous experiences of disasters } \\
\text { (Amundsen et al. 2010) } \\
\text { Donnor priorities and } \\
\text { condicionalities (Dodman et al. } \\
\text { 2012) }\end{array}$ & $\begin{array}{l}\text { Multi-actor's capacity for negotiation and } \\
\text { social learning (Burch et al. 2010) } \\
\text { Integration of disaster risk management and } \\
\text { adaptation policies (Howes et al. 2015, } \\
\text { Djalante et al. 2013) }\end{array}$ \\
\hline
\end{tabular}

Endogenous factors are important to the extent that they may palliate the lack of resources and capacity of some local governments and foster innovation for climate change action (Anguelovski and Carmin 2011). The cases of Durban, Quito, or Manizales demonstrate the potential of creative actions, 
particularly when they link new climate change agendas with ongoing sustainability actions and goals (Carmin et al. 2012, Bartlett and Satterthwaite 2016). Linking climate change action with additional cobenefits in the urban environment may be an effective way to motivate different actors to take action and foster shared creative processes (Sharma and Tomar 2010). However, Table 2 should not be read alongside as a check list of desirable outcomes. None of these factors alone explain the success of local governments in taking effective climate action.

In fact, different strategies may be effective depending on the context of action. For example, political leadership is one of the most often cited drivers of effective action (e.g. Burch 2010, Sanchez-Rodriguez 2009, Janjua et al. 2010, Shey and Belis 2013). On the other hand, forms of collaboration and selforganization appear to promote both resilience and climate change innovation, particularly alongside equity and social justice goals (Djalante et al. 2011, Sovacool 2011). An excessive focus on political leadership may work against self-organizing movements and experimental initiatives which have not been foreseen by policy makers. Often, local governments' experiences in climate governance are best described as a 'muddling through' process, in which policy makers may abandon aspirations to achieve a global, consensual vision of urban futures in favor of more pragmatic approaches that enable action (Marsden et al. 2014). However, such pragmatic treatment of governance realities may represent an abandonment of transformative aspirations (Bulkeley et al. 2014c), particularly in contexts characterized by lack of governance capacity in the first place (Simon and Leck 2015)

The one thing that seems to universally apply to every case is the need to understand the multi-level nature of urban governance, and harness it for climate change action. Ideas of multi-level governance acknowledge that local governments are not the only urban actors who can lead and deliver climate action (Betsill and Bulkeley 2006, Bulkeley and Betsill 2005b, Bulkeley and Betsill 2013). Instead, debates into governance have highlighted the key roles played by a myriad of state and non-state actors (Biermann and Pattberg 2012, Okereke et al. 2009). First, state actors at the national level provide 
crucial support to local governments and may be leading action at the local level (Jones 2013, Dodman and Mitlin 2015, Hughes 2013, Fidelman et al. 2013, van Stigt et al. 2013). Second, supra-national levels and international organizations play a crucial role in informing regulation and enabling innovation (Monni and Raes 2008). Finally, a range of other non-state actors, including business, networks and communities, play a key role in the governance of climate change in urban areas, opening up new areas of intervention and supporting action where there is little capacity, both in developed and developing countries (Leck and Simon 2013, Dodman and Satterthwaite 2008, Amundsen et al. 2010, Burch et al. 2014).

Attempts to look at multi-level governance in a normative way- as a means to order and coordinate different actors' actions- have been common in developed country contexts (e.g. Sperling et al. 2011, Jones 2012). Simultaneously, multi-level theories emerge in relation to an understanding of the messy and complex contexts in which governing happens, with multi-actor arrangements and ad hoc measures (Smith 2007). The notion of governance has a tinge of optimism, in the sense of finding new possibilities for climate change interventions in complex contexts of action, and increasing local government's capacity to deal with a complex problem (Khan 2013). However, this optimism needs to be balanced with a preoccupation for the deviation of responsibilities for the provision of urban services away from the state. This is particularly troublesome in urban areas where a sizeable proportion of the population lives in informal settlements, and the local government already struggles with service provision. For example, in Lusaka, Zambia, the lack of planning and appropriate policies means that the urban poor are left to themselves to resolve the increasing food insecurity challenges that follow the impacts of climate change in their city (Simatele et al. 2012).

Rethinking urban governance as multi-level also requires an examination of what is the role of planning in delivering effective climate change action. Spatial planning approaches focusing on sector integration have tended to dominate climate planning agendas (e.g. Pasimeni et al. 2014, Roggema 2014, Capon et 
al. 2009). However, in a multi-level governance context, where the main objective may rather be the legitimization and institutionalization of climate action, multi-actor, deliberative and collaborative planning approaches are more effective (Corfee-Morlot et al. 2011, Carter et al. 2015, Cashmore and Wejs 2014). Planning is also regarded as a process of knowledge co-production, that integrates a range of insights from global circulation models to situated experiences of disasters and energy use experiences (Castán Broto et al. 2015a, Hughes and Romero-Lankao 2014, Corburn 2009, HillmerPegram et al. 2012, Simon and Leck 2015). Participation is a key feature of effective local governance for climate change (Altenburg 2012). Participatory planning may deliver transformative outcomes by, for example, enabling new means of community-based adaptation (Archer et al. 2014, Castán Broto et al. 2015a); creating governance partnerships (Burch et al. 2014, Castán Broto et al. 2015b); dealing practically with institutional challenges (Barbour and Deakin 2012, Fatti and Patel 2013); facilitating social learning (Boyd et al. 2014, Djalante et al. 2013); and fostering innovation (Head 2014, Pitt and Bassett 2014). There is evidence, from a range of contexts in developed and developing countries, against the widely held belief that participatory planning costs more resources and time than a nonparticipatory planning (Naustdalslid 2015, Pitt and Bassett 2014, Smedby and Neij 2013, Castán Broto et al. 2015a). Participatory planning emerges as a long-term governance strategy, oriented towards the institutionalization of mechanisms for dialogue, action and innovation (Orleans Reed et al. 2013, Tran Tuan et al. 2014). The major challenge is to move away from the instrumental use of participatory methods for governance, towards deliberative approaches that recognize both the multiple capacities of urban actors and their right to participate in the making of sustainable urban futures.

\subsection{The role of cities and urban areas in transnational climate change governance}

City networks (and networks including other sub-national entities) play a key role in fostering, supporting and implementing climate action. First, they may support processes of learning and exchange between local governments and other sub-national organizations. Second, they may support specific 
policies, building critical mass to pool resources and knowledge. Third, they may have access to international forums, raising the profile of cities and urban areas in international agendas and garnering the interest of influential actors.

City (and sub-national) networks represent one of the most ubiquitous forms of transnational climate change governance, as explained in the book Transnational Climate Change Governance, a book coauthored by ten leading experts in global environmental politics (Bulkeley et al, 2014a). Transnational climate change governance is concerned with how different organizations act in international arenas so that they gain sufficient authority to steer international policy (Bulkeley et al. 2012, Andonova et al. 2009). This is a relatively recent phenomenon of rapid diffusion since the late 1980 s and early 1990 s, and it is associated both to the raise of global policy agendas (such as climate change) and to the internationalization processes that have followed broader processes of globalization and neoliberal ideologies (Bulkeley et al. 2014a). City networks emerge in a variety of forms with other forms of transnational climate change governance, alongside a continuum of public, private and hybrid actors (Bulkeley et al. 2012).

\begin{tabular}{|c|c|c|c|}
\hline Name & $\begin{array}{l}\text { Describe themselves } \\
\text { as: }\end{array}$ & Scope of operation & Significance \\
\hline $\begin{array}{l}\text { ICLEI- Local } \\
\text { Governments for } \\
\text { Sustainability } \\
\text { iclei.org }\end{array}$ & $\begin{array}{l}\text { "The leading global } \\
\text { network of more than } \\
\text { 1,500 cities, towns and } \\
\text { regions committed to } \\
\text { building a sustainable } \\
\text { future" }\end{array}$ & $\begin{array}{l}\text { They work directly } \\
\text { with 'members', local } \\
\text { governments, in } \\
\text { improving local } \\
\text { practices and have } \\
\text { policy influence } \\
\text { globally }\end{array}$ & $\begin{array}{l}\text { Formed in 1990, ICLEI } \\
\text { has played a key role in } \\
\text { driving forward } \\
\text { sustainability agendas. } \\
\text { ICLEI developed one } \\
\text { pioneering } \\
\text { methodology for } \\
\text { emission inventories }\end{array}$ \\
\hline
\end{tabular}




\begin{tabular}{|c|c|c|c|}
\hline $\begin{array}{l}\text { C40 Cities- Climate } \\
\text { Leadership Group } \\
\text { c40.org }\end{array}$ & $\begin{array}{l}\text { "A network of the } \\
\text { world's megacities [83] } \\
\text { committed to } \\
\text { addressing climate } \\
\text { change" }\end{array}$ & $\begin{array}{l}\text { The C40 coordinates } \\
\text { processes of } \\
\text { collaboration and } \\
\text { knowledge-sharing, as } \\
\text { well as developing city- } \\
\text { based metrics }\end{array}$ & $\begin{array}{l}\text { Formed in } 2005, \text { the } \\
\text { network has raised the } \\
\text { profile of the cities and } \\
\text { climate change } \\
\text { agenda, with famous } \\
\text { Mayors and the } \\
\text { intervention of the } \\
\text { Clinton Foundation }\end{array}$ \\
\hline $\begin{array}{l}\text { The World Mayors } \\
\text { Council on Climate } \\
\text { Change } \\
\text { worldmayorscouncil.org }\end{array}$ & $\begin{array}{l}\text { "An alliance of } \\
\text { committed local } \\
\text { government leaders } \\
\text { concerned about } \\
\text { climate change" }\end{array}$ & $\begin{array}{l}\text { The Council brings } \\
\text { together Mayors, } \\
\text { former Mayors and } \\
\text { Council Members who } \\
\text { make a personal } \\
\text { commitment to } \\
\text { political action for } \\
\text { climate change }\end{array}$ & $\begin{array}{l}\text { Founded in } 2005 \text { in } \\
\text { Kyoto, the Council has } \\
80 \text { members and has } \\
\text { worked to deliver } \\
\text { politically-savvy } \\
\text { initiatives that have } \\
\text { put climate change on } \\
\text { local agendas }\end{array}$ \\
\hline $\begin{array}{l}\text { United Cities and Local } \\
\text { Governments (UCLG) } \\
\text { uclg.org }\end{array}$ & $\begin{array}{l}\text { "United Cities and } \\
\text { Local Governments } \\
\text { (UCLG) represents and } \\
\text { defends the interests } \\
\text { of local governments } \\
\text { on the world stage, } \\
\text { regardless of the size } \\
\text { of the communities } \\
\text { they serve" }\end{array}$ & $\begin{array}{l}\text { UCLG mission is to } \\
\text { advocate democratic } \\
\text { self-governance, and } \\
\text { promote initiatives to } \\
\text { promote it, represent } \\
\text { local governments and } \\
\text { develop policy- many } \\
\text { of which relate to } \\
\text { climate change. }\end{array}$ & $\begin{array}{l}\text { Since their foundation } \\
\text { in } 2004, \text { UCLG has had } \\
\text { a strong voice in } \\
\text { shaping international } \\
\text { agendas, with a clear } \\
\text { pro-democratic } \\
\text { governance advocacy } \\
\text { agenda, which has also } \\
\text { promoted key climate } \\
\text { change policy. }\end{array}$ \\
\hline $\begin{array}{l}\text { Global Network of } \\
\text { Regional Governments } \\
\text { for Sustainable } \\
\text { Development (NRG4SD) } \\
\text { nrg4sd.org }\end{array}$ & $\begin{array}{l}\text { "A non-profit } \\
\text { international } \\
\text { organization } \\
\text { representing } \\
\text { subnational } \\
\text { governments and }\end{array}$ & $\begin{array}{l}\text { They have been behind } \\
\text { key initiatives such as } \\
\text { the Saint Malo } \\
\text { Declaration that led to } \\
\text { UNEP/UNDP } \\
\text { 'Territorial Approach }\end{array}$ & $\begin{array}{l}\text { Since their } \\
\text { establishment at the } \\
2002 \text { World Summit in } \\
\text { Johannesburg, } \\
\text { NRG4SD have worked } \\
\text { in partnership with UN }\end{array}$ \\
\hline
\end{tabular}




\begin{tabular}{|c|c|c|c|}
\hline & $\begin{array}{l}\text { associations of } \\
\text { subnational } \\
\text { governments at global } \\
\text { level" }\end{array}$ & $\begin{array}{l}\text { to Climate Change' } \\
\text { with initial projects in } \\
\text { Uganda, Uruguay, } \\
\text { Albania, Algeria, } \\
\text { Colombia, Ethiopia, } \\
\text { Perú and Senegal. }\end{array}$ & $\begin{array}{l}\text { organisations, linking } \\
\text { climate change } \\
\text { objectives with } \\
\text { Sustainable } \\
\text { Development Goals }\end{array}$ \\
\hline $\begin{array}{l}\text { R20 Regions of Climate } \\
\text { Action } \\
\text { Regions20.org }\end{array}$ & $\begin{array}{l}\text { "R20 is a coalition of } \\
\text { partners led by } \\
\text { regional governments } \\
\text { that work to promote } \\
\text { and implement } \\
\text { projects that are } \\
\text { designed to produce } \\
\text { local economic and } \\
\text { environmental } \\
\text { benefits" }\end{array}$ & $\begin{array}{l}\text { Mirroring the structure } \\
\text { and forms of operation } \\
\text { of C40, R20 puts } \\
\text { emphasis on } \\
\text { technologies and } \\
\text { modes of finance that } \\
\text { can deliver climate } \\
\text { action without } \\
\text { compromising } \\
\text { economic growth }\end{array}$ & $\begin{array}{l}\text { Founded by California } \\
\text { Governor Arnold } \\
\text { Schwarzenegger in } \\
2010 \text {, the network } \\
\text { recognizes different } \\
\text { levels of subnational } \\
\text { government. It has } 580 \\
\text { members and a strong } \\
\text { presence at the COP }\end{array}$ \\
\hline $\begin{array}{l}\text { Energy Cities } \\
\text { energy-cities.eu }\end{array}$ & $\begin{array}{l}\text { "The European } \\
\text { Association of local } \\
\text { authorities in energy } \\
\text { transition" }\end{array}$ & $\begin{array}{l}\text { The Association } \\
\text { develops proposals to } \\
\text { advance a transition, } \\
\text { to help their members } \\
\text { directly }\end{array}$ & $\begin{array}{l}\text { Created in 1990, the } \\
\text { network represent } \\
\text { more than } 1000 \text { local } \\
\text { governments in } \\
\text { Europe, mainly } \\
\text { municipalities }\end{array}$ \\
\hline $\begin{array}{l}\text { Covenant of Mayors } \\
\text { covenantofmayors.eu }\end{array}$ & $\begin{array}{l}\text { "Signatory local } \\
\text { authorities share a } \\
\text { vision for making cities } \\
\text { decarbonised and } \\
\text { resilient where citizens } \\
\text { have access to secure, } \\
\text { sustainable and } \\
\text { affordable energy" }\end{array}$ & $\begin{array}{l}\text { By signing the } \\
\text { Covenant, local } \\
\text { governments commit } \\
\text { to deliver a Sustainable } \\
\text { Energy and Climate } \\
\text { Action Plan and } \\
\text { establish a monitoring } \\
\text { process }\end{array}$ & $\begin{array}{l}\text { Over } 6000 \\
\text { 'democratically- } \\
\text { constituted local } \\
\text { governments' have } \\
\text { signed the covenant } \\
\text { since } 2005, \text { shaping } \\
\text { both local and } \\
\text { European Policy }\end{array}$ \\
\hline
\end{tabular}




\begin{tabular}{|c|c|c|c|}
\hline $\begin{array}{l}\text { Asian Cities Climate } \\
\text { Change Resilience } \\
\text { Network (ACCCRN) } \\
\text { acccrn.org }\end{array}$ & $\begin{array}{l}\text { "A multi-year initiative } \\
\text { to strengthen the } \\
\text { capacity of over } 50 \\
\text { rapidly urbanizing } \\
\text { cities in Bangladesh, } \\
\text { India, Indonesia, the } \\
\text { Philippines, Thailand } \\
\text { and Vietnam to } \\
\text { survive, adapt, and } \\
\text { transform in the face } \\
\text { of climate-related } \\
\text { stress and shocks" }\end{array}$ & $\begin{array}{l}\text { They work directly } \\
\text { with members, mainly } \\
\text { individual } \\
\text { practitioners, to } \\
\text { support the } \\
\text { development of } \\
\text { partnerships and } \\
\text { provide access to a } \\
\text { shared knowledge- } \\
\text { based }\end{array}$ & $\begin{array}{l}\text { Funded by the } \\
\text { Rockefeller } \\
\text { Foundation, the } \\
\text { ACCCRN has had a } \\
\text { strong influence in } \\
\text { collaborative } \\
\text { approaches to urban } \\
\text { resilience, and has } \\
\text { raised the profile of its } \\
\text { national partners, such } \\
\text { as the Mercy Corps } \\
\text { Indonesia }\end{array}$ \\
\hline $\begin{array}{l}\text { Japan, the Coalition of } \\
\text { Local Governments for } \\
\text { Environmental Initiative } \\
\text { (COLGEI) } \\
\text { Colgei.org }\end{array}$ & $\begin{array}{l}\text { Is a network of } \\
\text { members representing } \\
\text { local governments in } \\
\text { Japan }\end{array}$ & $\begin{array}{l}\text { Members include local } \\
\text { governments but also } \\
\text { other organizations, } \\
\text { such as universities or } \\
\text { concerned members of } \\
\text { the public }\end{array}$ & $\begin{array}{l}\text { Since the early 1990s, } \\
\text { COLGEI holds an } \\
\text { annual conference for } \\
\text { sharing practices and } \\
\text { experiences; works in } \\
\text { partnership with ICLEI }\end{array}$ \\
\hline
\end{tabular}

Table 3 compiles ten representative examples of networks of cities, urban areas and sub-national entities that are seeking to build authority in international climate change arenas. While not intending to be an exhaustive compilation, the table illustrates some of the trends in terms of what are these networks, how are they formed, and what do they try to achieve. Table 3 illustrates the diversity that characterizes those networks. First of all, networks differ on when they were established, with a spectrum from networks that have been long active and for which climate change has raised into their agendas (e.g. ICLEI, Energy Cities, UCLG) and networks that were inspired by climate change interests, with some networks formed after the ratification of the Kyoto Protocol in 2005 (e.g. C40, C20, The World Mayors Council on Climate Change). Second, networks differ in terms of the scale of their 
operation, with some of them aiming at global representation (ICLEI, C40, R20) while others operate at regional or national scales (Energy Cities, ACCCRN, COLGEI). Third, they may differ in their membership. It is generally assumed that they consist of local governments 'members', represented by either mayors or other local government leaders (e.g. ICLEI, C40). However, many networks consist of individuals in their personal capacity (World Mayors Council on Climate Change) or different organizations which may operate locally to deliver climate action (ACCCRN). In recognition of sub-national forms of governance other than municipalities and local government, regional networks have also been active in transnational climate governance (NRG4SD, R20).

Networks also differ in terms of their policy orientation and approach to climate policy. For example, ICLEI and NRG4SD link climate change action with other sustainable development agendas, and put emphasis in processes of governance, policy targets, and capacity building. Their carbon accounting tool, for example, has been instrumental in the developing of climate planning methodologies. Networks such as $\mathrm{C} 40$ and its regional counterpart, the R20, have a strongest focus on sharing advanced technologies and accessing finance, presenting climate action as a means to advance economic growth and the green economy. They have developed a strong profile in international events and have showcased best practices, often moving local politicians to make public commitments to climate change action. Some networks are better understood as advocacy organizations, such as UCLG which works to put local governments in international agendas and to advance normative discourses of local democratic selfgovernance. Other networks, such as the ACCRN, provide specific sectoral measures, such as those for building resilience (Brown et al. 2012). Networks emerge in a multitude of ways, whether this is through Mayor's agreements, supported by United Nations organizations, or sponsored by private funds such as the Clinton Foundation (which supported the creation of the C40) and the Rockefeller Foundation (which funds the ACCCRN). Overall, these are multiple networks which, despite their diversity, operate with high levels of cooperation. Table 4 illustrates various factors that demonstrate this diversity. 


\begin{tabular}{|c|c|c|}
\hline Scale of operation & \multicolumn{2}{|c|}{$\begin{array}{l}\text { Global } \\
\text { Regional (e.g. European Union, North America, Asia) } \\
\text { National }\end{array}$} \\
\hline Types of action undertaken & \multicolumn{2}{|c|}{$\begin{array}{l}\text { Membership and tailored support (e.g. ICLEI, UCLG) } \\
\text { Networking and showcasing activities (e.g. C40) } \\
\text { Enforcing collective commitments (e.g. Covenant of Mayors) }\end{array}$} \\
\hline Proposed climate action & \multicolumn{2}{|c|}{$\begin{array}{l}\text { Holistic approach to climate planning, through different types of } \\
\text { climate plans } \\
\text { Integration of climate change in ongoing local government } \\
\text { activities- climate change mainstreaming } \\
\text { Specific sectoral interventions (e.g. adaptation, sustainable energy, } \\
\text { water) } \\
\text { Collaborative approaches and partnership building }\end{array}$} \\
\hline \multirow[t]{2}{*}{ Governance structures } & Members & $\begin{array}{l}\text { Mayors representing cities } \\
\text { Mayors and other local leaders in their } \\
\text { personal capacity } \\
\text { Practitioners and policy-makers working in } \\
\text { local governments } \\
\text { Representatives of specific local government } \\
\text { departments } \\
\text { Specific organizations within cities, } \\
\text { governmental or not, that play a role in } \\
\text { climate leadership }\end{array}$ \\
\hline & $\begin{array}{l}\text { Management and } \\
\text { operation and } \\
\text { direction }\end{array}$ & $\begin{array}{l}\text { Independent body with member's steering } \\
\text { committee } \\
\text { Independent body, fully autonomous } \\
\text { Local governments coordination, with } \\
\text { rotating management responsibilities among } \\
\text { members } \\
\text { Sub-section of an existing NGO }\end{array}$ \\
\hline
\end{tabular}


Transnational climate change governance extends to developing countries, and it is common to have representation of members of the Global South in transnational networks (Bulkeley et al. 2012). As city and other sub-national networks have grown in number and interconnectedness, their role influencing global climate change agendas has become visible. Networks have to be understood in relation to new partnership approaches to climate diplomacy (Bäckstrand 2008), following the fragmentation of multilateral policies that constituted the holy grail of international negotiations until their collapse in Copenhagen in 2009. Following his analysis of the formation and influence of the C40, Acuto (2013) describes how the structuration of networks enables cities not just to expand their governance reach but also to constitute themselves as 'obligatory passage points' for transnational climate change governance. In particular, he argues that through the development of specific demonstrative projects, city networks are able to de-politicize climate debates to open up spaces of intervention- while presumably silencing dissenting voices. Networks have undoubtedly created momentum for 'practical policy action' (Dierwechter and Wessells 2013). There is, however, a question of what causes what, as the likelihood for cities to join networks and campaigns such as ICLEI's campaign Cities for Climate Protection (CCP) depends on endogenous factors such as perceived vulnerabilities and socioeconomiccapacity (Zahran et al. 2008) (see also section 2.2).

This new climate diplomacy spaces have made cities even more visible in international events (Hoffmann 2011). The first Climate Summit for Mayors took place in Copenhagen 2009, in parallel to the COP. Already then, the Mayor's dialogues were tinged by a tone of optimism and engagement with action on the ground, in contrast to the opaque negotiations between representatives of nation states at the COP. In 2011, the COP established the Ad Hoc Working Group on the Durban Platform for Enhanced Action (ADP), a subsidiary body with the mandate to develop a legal instrument to be applied under the convention. At the request of the ADP, the UNFCCC secretariat organized an unprecedented forum on best practices in cities and subnational authorities, on the 10 June 2013 (UNFCCC 2013). The 
event highlighted the importance of cooperation, voluntary action and participatory, people-oriented approaches, but it was not followed up in further ADP meetings. Mayoral events continued. The Nantes Declaration of Mayors and Subnational Leaders on Climate Change, in September 2013, urged national governments to consider seriously the potential of sub-national authorities in their efforts to tackle climate change. In 2015, the now-called Climate Summit for Local Leaders in Paris reaffirmed their commitment to climate change goals exceeding the goals agreed by national governments and stated that "advancing climate solutions is a shared responsibility, and a matter of rights, equality and social justice"1. The first commitment reveals the complementary role that cities and urban areas play to meet carbon reduction aspirations, in the context of the Paris Agreement that, while constituting a diplomatic success, falls short from global ambitions to keep temperature changes within safe levels. ICLEI's Transformative Actions Programme (TAP), in partnership with twelve other networks and NGOs, aims to "to maximize investment in low-carbon and climate-resilient urban development and governance processes", thus demonstrating that action in cities is something more than a nice addition to national efforts: it is truly transformative local action that can make a difference to carbon reduction and resilience commitments (ICLEI 2015).

The second statement, which reconfigures climate politics around discourses of rights and responsibilities, represents a relatively radical redefinition of global climate change discourses, staging justice concerns in local climate change policy (Bulkeley et al. 2013). In doing so, city networks reveal the role they may play in creating new paradigms for climate governance, thus reconfiguring climate politics, for example, by redefining justice struggles in relation to the experiences of urban citizens, rather than abstract concepts of global climate justice. In that sense, urban governance is neither just a

\footnotetext{
${ }^{1}$ Climate Summit for Local Leaders, Paris City Hall Declaration, available at http://climatesummitlocalleaders.paris/content/uploads/sites/16/2016/01/CLIMATE-SUMMIT-LOCAL-LEADERSPOLITICAL-DECLARATION-PARIS-DEC-4-2015.pdf (last accessed 31/05/2016).
} 
mechanism to deal with climate change issues in specific contexts nor a means to gain influence in global spheres to redirect climate finance to urban areas: instead, urban governance constitutes a means to build new forms of authority over both the city and climate change; means that have to be studied from a critical perspective, as explained in the following section. 


\section{Urban governance as a means to gain control and authority}

A perspective on urban governance as a means to gain authority turns attention away from how to do 'good governance', and looks instead into who, why and with what consequences urban governance is accomplished. This perspective "starts from the analysis of governing as the orchestration of distinct modes of power" seeking to explore its operation (Bulkeley 2015; p. 3). These are not just wellintentioned means to respond to an urgent problem, but complex political entanglements which reveal the underlying paradigms and the contexts of intervention in which governing actors operate. The literature is presented in two sections, the first looking at how climate politics play out in local contexts, and the second, at how governing climate change in urban areas is reconfiguring climate politics, via the deployment of specific discourses of innovation, experimentation and transformation.

\subsection{The production of climate politics at the local context}

Governance may be a means to control and dominate actors, things, and events. Critical theory, however, has highlighted how the act of governing emerges from within the circumstances in which it is accomplished. Rather than being a mere mechanism of control, governance should be understood as a mechanisms of orchestration which sometimes requires domination, but most times works upon mechanisms of seduction and inducement, as it is carefully explained in the book Accomplishing Climate Governance (Bulkeley 2015). A modern reinterpretation of Foucault's notion of governmentality, as the rationalities that facilitate 'the art of government', has sparkled thought about the nature and operation of urban governance mechanisms (Bulkeley et al. 2014c). Bulkeley (2015) relates climate change 'governmentalities' with the redefinition of power as relational, that is, as emerging from the coordination and negotiation of actors whereby power is consented. Such forms of governing unfold as open-ended processes, characterized by unexpected events. Finally, governmental technologies are 
implicated in the creation of subjects which enact particular discourses of action through their own conduct (Bulkeley 2015).

The relational dimensions of governmentality are manifest, for example in the attribution of responsibilities for climate change, which is linked to dilemmas about who should act and what is the most appropriate scale for action (Lundqvist and von Borgstede 2008). Positive views on the proliferation of actors in urban governance contrast with perspectives that see in this profusion of actors as the root cause of a dilution of responsibilities thus constraining carbon reduction and climate protection efforts (Marsden and Rye 2010, Newell et al. 2012). Recent research has engaged with the emergence of 'strategic intermediary organizations', or simply 'intermediaries', which under the umbrella of climate action play a key role in reconfiguring urban politics (Hodson and Marvin 2009, Hodson et al. 2013). The governance of climate change in cities requires the formation of actorconstellations mediating social, institutional and technological change (Rohracher and Spath 2014). However, intermediaries play a central role in the orchestration of those constellations, because they are able to use global discourses of climate change to shape local processes (Hodson et al. 2013, Fischer and Guy 2009). Intermediaries include a diverse, complex and interrelated set of actors- NGOs, unions, private consultancies, designers, regulators, and even travel agents, just to mention some- who mediate and work in between other actors, sharing, regulating and most of all, controlling a diverse set of production and consumption processes involved in low carbon, climate resilient transitions (Guy et al. 2011). In developing countries, middling technocrats, those who internalize global environmental concerns and deploys them in specific contexts for the reproduction of the space (Roy and Ong 2011), may play key intermediation roles.

From a governmentality lens, governing is akin to defining the problem which is to be governed, looking for framing strategies which enable the reproduction of authority. Here, the urban can be located in relation to broader institutional and economic networks, linking near and far places that shape climate 
change politics (Rutherford and Coutard 2014). Urban regime theory has looked at the city as a site of power pluralism, where power fragmentation generates a need to build authority through processes of intermediation and negotiation (Shey and Belis 2013, Mossberger and Stoker 2001). Urban regime theory fits a city that follows the logic of markets, and disregards local politics in favor of efficiencyoriented forms of coordination. This approach explains how environmental policy is often tied to ideas of economic competitiveness and technological development, such as, for example, in smart cities and green economy discourses (Herrschel 2013, de Oliveira et al. 2013), in efficiency-oriented spatial and economic planning (Hu 2015, Storbjork and Hjerpe 2014, Taylor et al. 2012) and in economic-oriented demonstration projects of sub-national networks such as the C40 and the R20 (see secion 2.3). However, urban regime theory's emphasis on the city as a site of entrepreneurialism has meant that it has largely neglected the regulatory impulses embedded in discourses of resilience building and carbon control (Jonas et al. 2011). Overall, the encounter of urban regime theory with climate change governmentalities speaks of a contradiction between the impulse to control the city and the suspicion of state-led forms of control embedded in the local politics of climate change.

One key issue in establishing forms of resilience and carbon governance is that of measuring, both in terms of measuring climate impacts and in estimating the need for carbon reductions (e.g. Pearce and Cooper 2011, Rice 2010, Bulkeley 2015). The idea of 'calculus', frequently associated with governmentalities, speaks here of the need to associate actions with narratives that provide a rationale for intervention. This represents efforts to link local contexts of action- material, spatial, social- to the actual possibilities of intervention, both to legitimate diverse climate publics and demonstrate the effectiveness of the proposed action (Knuth 2010). Scholars of innovation, particularly, have looked at urban infrastructure regimes to explain how knowledge and institutions are configured together with the material artefacts that constitute infrastructure networks (Monstadt 2009). In contrast to urban regime theory, regimes here refer to dominant configurations that shape the social and material aspects 
of urban life and which may become unstable under global pressures. Climate change politics is deployed here as a means to organize materials and spaces, orchestrating new modes of service provision and alternative urban futures, only possible through the development of new modes of calculation (Bulkeley et al. 2014c).

Foucault famously described governing as the conduct of conduct. Governmentalities direct attention to processes of self-governing, whereby individuals attempt to regulate the behaviors of themselves and others. Self-governing has long been recognized as an important mode of governance in municipal governments that, given their control of buildings and infrastructures, attempt to 'lead by example' (Bulkeley and Kern 2006). The creation of self-governing subjects is also related to an emphasis on individual behavior change. Local governments in developed countries such as the UK and the US have actively encouraged a pro-environmental behavior change in the population, with the consequent displacement of responsibilities for carbon reduction (Revell 2013, Rice 2014). As climate change is framed as a problem that can be addressed via consumer choice, so local authorities and other intermediaries have been casted in the role of educators, whose actions are directed towards the creation of subjects through mechanisms of carbon control (While et al. 2010, Dowling et al. 2014). In vulnerable cities in the developing world, the creation of climate change subjects may be directed towards the creation of citizens capable of dealing with the consequences of disasters, so that responsibility for safety and service provision is once again displaced to the urban poor, who suffer the most and have least access to global resources (see for example this concern explained in: Douglas et al. 2008).

Both urban regime theory and governmentality-inspired approaches to urban governance have sparkled creative interpretations of how the politics of climate change unfold in urban locales. City actors may attempt to build authority and legitimate their interventions through orchestration and self-governing from the institutions that are attributed responsibility for action to the individuals that respond to 
climate change by engaging in climate-sensitive consumer choices. Yet, in both cases there is a tendency to overlook how conflict shapes political struggles. At a fundamental level, there is a question of how the encounter between discursive narrations of intervention encounter the actual realities of implementation, which is often experienced as a contradiction in governance (Castán Broto 2015). At a more mundane level, these theories downplay how existing institutions and material arrangements exclude actors from the possibility of exercise control over the city, and how the urban governance of climate change is also embedded in processes of contestation and political struggle (Rutherford and Coutard 2014). Paradoxically, by highlighting forms of situated agency, governmentality theory questions the extent to which dominant paradigms of action and change can be challenged or even just disrupted by those who necessarily operate within that paradigm.

\subsection{The rise of experimentation in global climate politics}

Theories of experimental governance follow both empirical observations of what actually happens in cities- how governance is accomplished- and theorizations of transformation and change that relate governing rationalities to situated agencies. This is perhaps an example of how processes of urban governance have shaped the politics of climate change beyond the arena of urban interventions. Urban areas are now looked at by consultants, business innovators, and other intermediaries as laboratories where new policy and technological innovations can be essayed (Evans and Karvonen 2014, Evans 2011). The appeal of experimental approaches is clear:

"The concept of experimentation feeds on attractive notions of innovation and creativity (both individual and collective) while reframing the emphasis of sustainability from distant targets and government policies to concrete and achievable actions..." (Evans et al. 2016)

Experimentation is often distinguished from other climate change governance strategies such as negotiation or standardization (Wejs 2014), but in practice, experimentation- associated with a vague 
promise of alternative urban futures and social innovation- is the dominant form of climate change governance in urban areas (Bulkeley et al. 2014c, Bulkeley and Castan Broto 2013). The global extent of experimentation as a form of governance has changed debates on the politics of climate change, with seminal pieces such as Hoffman (2011)'s book 'Climate governance at the crossroads: experimenting with a global response after Kyoto'.

Govermentality theory supports the notion that change aspirations follow a 'will to improve' (Li, 2007) whereby 'improvers' find mechanisms to enforce different conducts. Experiments are thus central to the development of specific intervention rationales and the processes of self-regulation that move both 'improvers' are those who 'receive' such improvement. Experimentation also fits theories of governance in which governing is never quite accomplished, but always in-the-making (Cochrane 2010). Following this, Bulkeley et al (2014) have developed a framework to characterize experiments as they travel through specific contexts of urban change. The MML framework refers to three interrelated processes that experiments go through as 'making', 'maintaining' and 'living'. Making refers to the need to assemble a wide range of elements together for the experiment to work. There is a need to link the actual material actions to suitable narratives that link the experiment to the objectives of addressing climate change. Governing requires, first of all, assembling the means for that governing. Experiments also have to be maintained, both because they need upkeep and repairs to work over relatively long periods of time and because they need to be integrated within the dynamic context of the city. This means material integration in physical networks as much integration with discourses of urban governance that cast it as relevant and imagine it as new and innovative. Mere integration alone may miss the experimental character of the action (Castán Broto and Bulkeley, 2014). Experiments are also lived, that is, they are integrated in daily routines. In this way, experiments shape and make conducts, constructing and solidifying specific government rationalities that may then transcend the experimental context and modifying urban life (Bulkeley et al, 2014). This framework enables a historicist account of experiments 
as embedded in particular contexts of action and relates them with context-based theories of change. In this perspective, experiments become complex processes of arrangement and trying, where both the constitution of the experiment (its transformative potential) and the receptivity of the situation (the milieu viscosity) influence the potential for transformation (Figure 1).

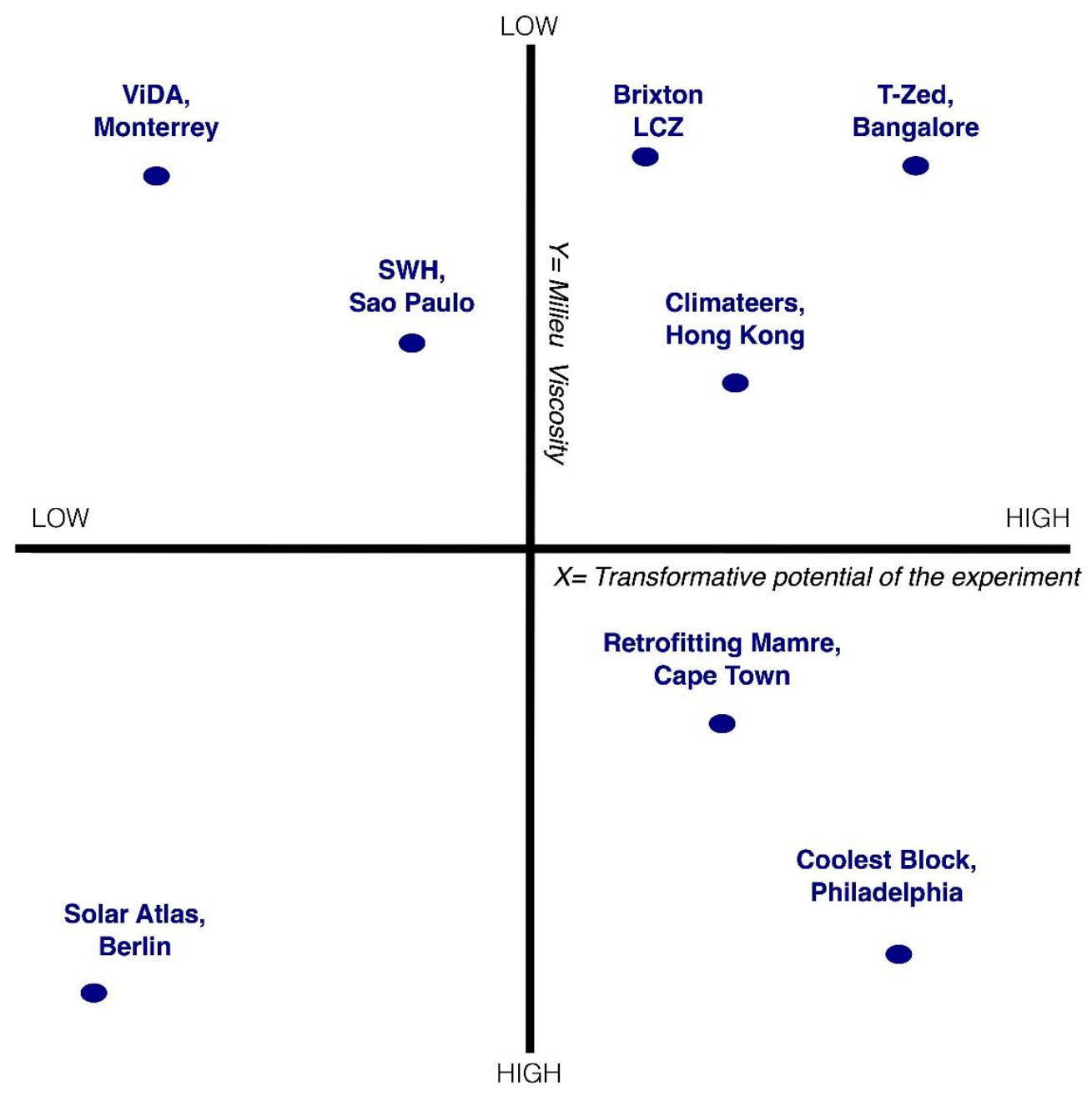

Figure 1: Impact of climate change experiments depending on their 'transformative potential' and their 'milieu viscosity' (originally published in Bulkeley et al, 2014; used with permission)

Experimentation relates climate politics with the practical dimensions of intervention (Evans 2011). In doing so, experimentation ties climate change action to specific actors, blurring forms of private and public authority and redefining intervention as forms of technical intervention in infrastructure 
networks (Bulkeley and Castan Broto 2013). The mechanisms for influencing broader climate change politics beyond the city are varied, but the following examples illustrate their importance:

- Experimentation has gained currency as a means to deal with the complexity and uncertainty inherent to climate change issues because it allows for initiatives which have tangible and measurable results but they do not need to be conclusive to be persuasive and convincing (Stead 2016).

- Experiments are often linked to demonstrations, as a means to visualize, materialize or prove innovative or unusual ideas to facilitate transformations. New forms of calculation in an uncertain context have to be actively performed to gain validity (Cidell 2015). Evans et al (2016), for example, mention Bogotá as an example of 'experimental city' whose perceived success went on to inspired interventions elsewhere in the world, to the point that some of the rationales for intervention become adopted as global discourses. The city is thus approached as an strategic space in which broader climate politics can be essayed and redefined (McGuirk et al. 2014).

- Experimentation is also tied to grassroots initiatives that attempt to bring utopian visions of the city, so that activities directed towards contesting hegemonic urban visions become in themselves attempts at governing the city (see examples in: Bulkeley et al. 2010, Evans et al. 2016). Ideas of experimental governance have helped to legitimize actors often excluded from global international politics, thus questioning the structuration of the international climate regime in relation to nation states and international diplomacy (Hoffmann 2011)

For all its emphasis on open-ended processes in governance, experimentation has often been approached in an instrumental way. As discourses of urban governance become technical, there follows an increasing emphasis on controlling experiments themselves and actively affirming the strategic role 
of cities and urban areas in climate change politics. The proliferation of projects that recast the city as a laboratory represent attempts to harness the experiments' power in controlled conditions, most often "reinforcing spatial differentiation and uneven participation in urban development" (Evans and Karvonen 2014). Often, urban laboratories bring discussions of knowledge co-production and participation back to institutionalist arguments about the need for visionaries who provide leadership in urban governance, whether this is within local governments or beyond (see for example: Nevens et al. 2013). Notions of innovation, experimentation and urban laboratories contribute to the proliferation of fantasy plans for property development in cities in developing countries such as Kigali, Lagos, Nairobi or Dar es Salam. This urban fantasies are seldom realized, but nevertheless have enormous impact on the lives of people, for example, with the removal of less powerful groups from land earmarked for development and the lack of recognition that these plans afford to people deemed to be living in 'empty land' (Watson 2013). Overall, beyond instrumental notions of good governance we lack a theory which can constitute a foundation for a progressive politics of climate change and which can activate positive, emancipatory action within urban areas and beyond. 


\section{Concluding thoughts}

This review serves as a reminder of the enormous interest generated by debates about cities and climate change. Urban governance is, however, still thought of as a complement, rather than a principal means to govern climate change. Given that the proposed voluntary contributions from nation-states will fall far from the aspiration of keeping changes in temperature under 1.5 degree in the 2015 Paris Agreement, there is a need to understand the contribution that non-state actors can make to mitigation objectives, particularly in urban areas.

Clearly, scholarly and policy efforts are moving in this direction. In 2015 and 2016 we have witnessed profound changes in international discourses of climate change and sustainable development. Now that an explicit urban goal has been included in the Sustainable Development Goals and that international organizations focus on harnessing 'the transformative power of urbanization', the idea that cities were once regarded as environmental parasites preying in its immediate hinterland sounds outlandish. Yet, many were the voices that focused on urbanization control in the Habitat II conference in Istanbul, in 1996, much to the dismay of militant urbanists who see their positive views on urban development ratified in the current international mood.

Urban areas and cities are, most of all, complex and heterogeneous arrangements of people, discourses and artefacts, in which history and future visions come together in encounters and events. The city is neither a perfectly oiled machine of synchronized components, nor is a random agglutination of human activities. Cities pollute as much as they restore; they both destroy and create. Neither they are parasites nor are they the holy grail of human organization. Most of all, cities are so different, so contingent, that it does not make sense to build cities on a common global objective or shared recipes for best practice. Rather, recognizing their history, the way social and material relations have been produced and the trajectories that shape people's lives are essential components of any process of 
urban governance, let alone one directed towards addressing an existential crisis such as climate change.

While it is now commonplace to assume the important role that cities and urban areas can play in addressing climate change, what is far less understood is the profound impact that the translation of climate change discourses has had on urban governance. Climate change has become an issue to be addressed in cities, whereby cities may structure plans and struggle to compete in international arenas. Climate change has become a driver of urban innovation, a political arena where city initiatives can be showcased. A myriad of actors in urban areas play a role in climate change politics demonstrating innovation, implementing ideas, bringing action to scale, recognizing vulnerabilities, and doing additional voluntary contributions that contribute to reduce carbon emissions overall.

Compelling questions remain to understand the extent to which urban governance experiences can truly challenge and reconfigure climate change politics. A demonstration and showcasing ethos in urban areas, evident in climate change experiments, moves away from finding the minimum common denominator. Instead, it seeks to establish the best possible outcomes that can be attained with the existing capacities and resources. The idea that a low carbon, climate resilient city should also be a just one may be the greatest contribution of urban governance debates to the politics of climate change. 


\section{Bibliography}

Acuto, M., 2013. Global cities, governance and diplomacy: The urban link. Routledge.

Adelekan, I., et al. 2015. Disaster risk and its reduction: an agenda for urban Africa. International Development Planning Review, 37(1), 33-43.

Altenburg, C., 2012. Institutional and social capacities in lead cities in Europe and the United States: success factors for urban sustainability? In: Holt, W. G. ed. Urban Areas and Global Climate Change. 3-28.

Amundsen, H., Berglund, F. and Westskog, H. 2010. Overcoming barriers to climate change adaptation a question of multilevel governance? Environment and Planning C-Government and Policy, 28(2), 276-289.

Andonova, L. B., Betsill, M. M. and Bulkeley, H. 2009. Transnational climate governance. Global Environmental Politics, 9(2), 52-73.

Anguelovski, I. and Carmin, J. 2011. Something borrowed, everything new: innovation and institutionalization in urban climate governance. Current Opinion in Environmental Sustainability, 3(3), 169-175.

Anguelovski, I., et al. 2016. Equity Impacts of Urban Land Use Planning for Climate Adaptation Critical Perspectives from the Global North and South. Journal of Planning Education and Research, $0739456 \times 16645166$.

Archer, D., et al. 2014. Moving towards inclusive urban adaptation: approaches to integrating community-based adaptation to climate change at city and national scale. Climate and Development, 6(4), 345-356.

Azevedo, I., Delarue, E. and Meeus, L. 2013. Mobilizing cities towards a low-carbon future: Tambourines, carrots and sticks. Energy Policy, 61, 894-900. 
Bache, I., et al. 2015. Blame Games and Climate Change: Accountability, Multi-Level Governance and Carbon Management. British Journal of Politics \& International Relations, 17(1), 64-88.

Bäckstrand, K. 2008. Accountability of networked climate governance: The rise of transnational climate partnerships. Global Environmental Politics, 8(3), 74-102.

Bahadur, A. and Tanner, T. 2014. Transformational resilience thinking: putting people, power and politics at the heart of urban climate resilience. Environment and Urbanization, 26(1), 200-214.

Baker, J. L., 2012. Climate change, disaster risk, and the urban poor: cities building resilience for a changing world. World Bank Publications.

Banks, N., Roy, M. and Hulme, D. 2011. Neglecting the urban poor in Bangladesh: research, policy and action in the context of climate change. Environment and Urbanization, 23(2), 487-502.

Barbour, E. and Deakin, E. A. 2012. Smart Growth Planning for Climate Protection Evaluating California's Senate Bill 375. Journal of the American Planning Association, 78(1), 70-86.

Barnett, C. and Parnell, S. 2016. Ideas, implementation and indicators: epistemologies of the post2015 urban agenda. Environment and Urbanization, 28(1), 87-98.

Bartlett, S. and Satterthwaite, D., 2016. Cities on a Finite Planet: Towards Transformative Responses to Climate Change. Routledge.

Betsill, M. and Bulkeley, H. 2007. Looking back and thinking ahead: a decade of cities and climate change research. Local Environment, 12(5), 447-456.

Betsill, M. M. and Bulkeley, H. 2006. Cities and the multilevel governance of global climate change. Global Governance: A Review of Multilateralism and International Organizations, 12(2), 141-159. Biermann, F. and Pattberg, P. H., 2012. Global environmental governance reconsidered. MIT Press. Birkmann, J., et al. 2010. Adaptive urban governance: new challenges for the second generation of urban adaptation strategies to climate change. Sustainability Science, 5(2), 185-206. 
Boyd, E., et al. 2014. Environmentalities of urban climate governance in Maputo, Mozambique. Global Environmental Change-Human and Policy Dimensions, 26, 140-151.

Boyd, E. and Folke, C., 2011. Adapting institutions: Governance, complexity and social-ecological resilience. Cambridge University Press.

Boyd, E. and Ghosh, A. 2013. Innovations for enabling urban climate governance: evidence from Mumbai. Environment and Planning C-Government and Policy, 31(5), 926-945.

Brown, A., Dayal, A. and del Rio, C. R. 2012. From practice to theory: emerging lessons from Asia for building urban climate change resilience. Environment and Urbanization, 24(2), 531-556.

Bulkeley, H., 2010. Cities and the Governing of Climate Change. In: Gadgil, A. and Liverman, D. M. eds. Annual Review of Environment and Resources, Vol 35. 229-253.

Bulkeley, H., 2013. Cities and Climate Change.

Bulkeley, H., 2015. Accomplishing Climate Governance. Cambridge University Press.

Bulkeley, H., et al. 2012. Governing climate change transnationally: assessing the evidence from a database of sixty initiatives. Environment and Planning C: Government and Policy, 30(4), 591-612. Bulkeley, H., et al., 2014a. Transnational climate change governance. Cambridge University Press. Bulkeley, H. and Betsill, M. M., 2005a. Cities and climate change: urban sustainability and global environmental governance. Psychology Press.

Bulkeley, H. and Betsill, M. M. 2005b. Rethinking sustainable cities: Multilevel governance and the 'urban' politics of climate change. Environmental Politics, 14(1), 42-63.

Bulkeley, H. and Betsill, M. M. 2013. Revisiting the urban politics of climate change. Environmental Politics, 22(1), 136-154.

Bulkeley, H., et al., 2010. Cities and low carbon transitions. Routledge.

Bulkeley, H., Broto, V. C. and Maassen, A. 2014b. Low-carbon Transitions and the Reconfiguration of Urban Infrastructure. Urban Studies, 51(7), 1471-1486. 
Bulkeley, H., et al. 2013. Climate justice and global cities: mapping the emerging discourses. Global Environmental Change, 23(5), 914-925.

Bulkeley, H. and Castan Broto, V. 2013. Government by experiment? Global cities and the governing of climate change. Transactions of the Institute of British Geographers, 38(3), 361-375.

Bulkeley, H. and Kern, K. 2006. Local government and the governing of climate change in Germany and the UK. Urban Studies, 43(12), 2237-2259.

Bulkeley, H. and Newell, P., 2015. Governing climate change. Routledge.

Bulkeley, H. A., Broto, V. C. and Edwards, G. A., 2014c. An urban politics of climate change: experimentation and the governing of socio-technical transitions. Routledge.

Burch, S. 2010. Transforming barriers into enablers of action on climate change: Insights from three municipal case studies in British Columbia, Canada. Global Environmental Change-Human and Policy Dimensions, 20(2), 287-297.

Burch, S., et al. 2014. Triggering transformative change: a development path approach to climate change response in communities. Climate Policy, 14(4), 467-487.

Burch, S., et al. 2010. Planning for climate change in a flood-prone community: municipal barriers to policy action and the use of visualizations as decision-support tools. Journal of Flood Risk Management, 3(2), 126-139.

Capon, A. G., Synnott, E. S. and Holliday, S. 2009. Urbanism, climate change and health: systems approaches to governance. New South Wales public health bulletin, 20(1-2), 24-28.

Carmin, J., Anguelovski, I. and Roberts, D. 2012. Urban Climate Adaptation in the Global South: Planning in an Emerging Policy Domain. Journal of Planning Education and Research, 32(1), 18-32. Carter, J. G., et al. 2015. Climate change and the city: Building capacity for urban adaptation. Progress in Planning, 95, 1-66. 
Cashmore, M. and Wejs, A. 2014. Constructing legitimacy for climate change planning: A study of local government in Denmark. Global Environmental Change-Human and Policy Dimensions, 24, 203212.

Castán Broto, V. 2015. Contradiction, intervention, and urban low carbon transitions. Environment and Planning D: Society and Space, 33(3), 460-476.

Castán Broto, V. and Bulkeley, H. 2013. A survey of urban climate change experiments in 100 cities. Global Environmental Change, 23(1), 92-102.

Castán Broto, V., et al., 2015a. Participatory Planning for Climate Compatible Development in Maputo, Mozambique/Planeamento participativo para o desenvolvimento compatível com o clima em Maputo, Moçambique. London: UCL Press.

Castán Broto, V., et al. 2015b. Building collaborative partnerships for climate change action in Maputo, Mozambique. Environment and Planning A, 47(3), 571-587.

Castán Broto, V., Oballa, B. and Junior, P. 2013. Governing climate change for a just city: challenges and lessons from Maputo, Mozambique. Local Environment, 18(6), 678-704.

Cidell, J. 2015. Performing leadership: municipal green building policies and the city as role model. Environment and Planning C-Government and Policy, 33(3), 566-579.

Cidell, J. and Cope, M. A. 2014. Factors explaining the adoption and impact of LEED-based green building policies at the municipal level. Journal of Environmental Planning and Management, 57(12), $1763-1781$.

Cochrane, A. 2010. Exploring the Regional Politics of 'Sustainability': Making Up Sustainable Communities in the South-East of England. Environmental Policy and Governance, 20(6), 370-381. Committee, B. o. t. P., 2016. Zero draft of the New Urban Agenda. Nairobi: UN-Habitat. Corburn, J. 2009. Cities, Climate Change and Urban Heat Island Mitigation: Localising Global Environmental Science. Urban Studies, 46(2), 413-427. 
Corfee-Morlot, J., et al. 2011. Multilevel risk governance and urban adaptation policy. Climatic Change, 104(1), 169-197.

de Oliveira, J. A. P., et al. 2013. Green economy and governance in cities: assessing good governance in key urban economic processes. Journal of Cleaner Production, 58, 138-152.

Dierwechter, Y. and Wessells, A. T. 2013. The Uneven Localisation of Climate Action in Metropolitan Seattle. Urban Studies, 50(7), 1368-1385.

Djalante, R., Holley, C. and Thomalla, F. 2011. Adaptive Governance and Managing Resilience to Natural Hazards. International Journal of Disaster Risk Science, 2(4), 1-14.

Djalante, R., et al. 2013. Pathways for adaptive and integrated disaster resilience. Natural Hazards, 69(3), 2105-2135.

Dodman, D. 2009. Blaming cities for climate change? An analysis of urban greenhouse gas emissions inventories. Environment and Urbanization, 21(1), 185-201.

Dodman, D., Bicknell, J. and Satterthwaite, D., 2012. Adapting Cities to Climate Change:

Understanding and addressing the development challenges. Routledge.

Dodman, D. and Mitlin, D. 2015. The national and local politics of climate change adaptation in Zimbabwe. Climate and Development, 7(3), 223-234.

Dodman, D. and Satterthwaite, D. 2008. Institutional Capacity, Climate Change Adaptation and the Urban Poor. Ids Bulletin-Institute of Development Studies, 39(4), 67-+.

Douglas, I., et al. 2008. Unjust waters: climate change, flooding and the urban poor in Africa. Environment and Urbanization, 20(1), 187-205.

Dowling, R., McGuirk, P. and Bulkeley, H. 2014. Retrofitting cities: Local governance in Sydney, Australia. Cities, 38, 18-24. 
Ensor, J., et al. 2014. Building adaptive capacity in the informal settlements of Maputo: lessons for development from a resilience perspective. Climate change adaptation and development: Transforming paradigms and practices. London: Routledge.

Evans, J. and Karvonen, A. 2014. 'Give Me a Laboratory and I Will Lower Your Carbon Footprint!' Urban Laboratories and the Governance of Low-Carbon Futures. International Journal of Urban and Regional Research, 38(2), 413-430.

Evans, J., Karvonen, A. and Raven, R., 2016. The Experimental City. Routledge.

Evans, J. P. 2011. Resilience, ecology and adaptation in the experimental city. Transactions of the Institute of British Geographers, 36(2), 223-237.

Fatti, C. E. and Patel, Z. 2013. Perceptions and responses to urban flood risk: Implications for climate governance in the South. Applied Geography, 36, 13-22.

Fidelman, P. I. J., Leitch, A. M. and Nelson, D. R. 2013. Unpacking multilevel adaptation to climate change in the Great Barrier Reef, Australia. Global Environmental Change-Human and Policy Dimensions, 23(4), 800-812.

Finnis, J., Sarkar, A. and Stoddart, M. C. J. 2015. Bridging science and community knowledge? The complicating role of natural variability in perceptions of climate change. Global Environmental Change-Human and Policy Dimensions, 32, 1-10.

Fischer, J. and Guy, S. 2009. Re-interpreting regulations: architects as intermediaries for low-carbon buildings. Urban Studies, 46(12), 2577-2594.

Francesch-Huidobro, M. 2012. Institutional deficit and lack of legitimacy: the challenges of climate change governance in Hong Kong. Environmental Politics, 21(5), 791-810.

Frantzeskaki, N., et al., 2016. Urban Sustainability Transitions. London: Routledge. 
Gebre-Egziabher, A., 2004. Sustainable Cities Programme: A joint UN-HABITAT-UNEP facility on the urban environment with participation of the Dutch government. In: AlfsenNorodom, C., Lane, B. D. and Corry, M. eds. Urban Biosphere and Society: Partnership of Cities. 62-79.

Guy, S., Marvin, S. and Medd, W., 2011. Shaping urban infrastructures: intermediaries and the governance of socio-technical networks. Routledge.

Hallegatte, S. and Corfee-Morlot, J. 2011. Understanding climate change impacts, vulnerability and adaptation at city scale: an introduction. Climatic Change, 104(1), 1-12.

Head, B. W. 2014. Evidence, uncertainty, and wicked problems in climate change decision making in Australia. Environment and Planning C-Government and Policy, 32(4), 663-679.

Herrschel, T. 2013. Competitiveness AND Sustainability: Can 'Smart City Regionalism' Square the Circle? Urban Studies, 50(11), 2332-2348.

Hillmer-Pegram, K. C., et al. 2012. A geographic approach to facilitating local climate governance: From emissions inventories to mitigation planning. Applied Geography, 34, 76-85.

Hodson, M. and Marvin, S. 2009. Cities mediating technological transitions: understanding visions, intermediation and consequences. Technology Analysis \& Strategic Management, 21(4), 515-534. Hodson, M., Marvin, S. and Bulkeley, H. 2013. The Intermediary Organisation of Low Carbon Cities: A Comparative Analysis of Transitions in Greater London and Greater Manchester. Urban Studies, 50(7), 1403-1422.

Hoffmann, M. J., 2011. Climate governance at the crossroads: experimenting with a global response after Kyoto. Oxford University Press.

Hoornweg, D., Sugar, L. and Trejos Gómez, C. L. 2011. Cities and greenhouse gas emissions: moving forward. Environment and Urbanization, 23(1), 207-227. 
Hordijk, M., Sara, L. M. and Sutherland, C. 2014. Resilience, transition or transformation? A comparative analysis of changing water governance systems in four southern cities. Environment and Urbanization, 26(1), 130-146.

Howes, M., et al. 2015. Towards networked governance: improving interagency communication and collaboration for disaster risk management and climate change adaptation in Australia. Journal of Environmental Planning and Management, 58(5), 757-776.

Hu, R. 2015. Sustainability and Competitiveness in Australian Cities. Sustainability, 7(2), 1840-1860. Hughes, S. 2013. Authority Structures and Service Reform in Multilevel Urban Governance: The Case of Wastewater Recycling in California and Australia. Urban Affairs Review, 49(3), 381-407. Hughes, S. and Romero-Lankao, P. 2014. Science and institution building in urban climate-change policymaking. Environmental Politics, 23(6), 1023-1042.

ICLEI, 2015. Transformative Actions Programme (TAP) Bonn: ICLEI. Janjua, S., Thomas, I. and McEvoy, D. 2010. Framing climate change adaptation learning and action: the case of Lahore, Pakistan. International Journal of Climate Change Strategies and Management, 2(3), 281-296.

Jonas, A. E. G., Gibbs, D. and While, A. 2011. The New Urban Politics as a Politics of Carbon Control. Urban Studies, 48(12), 2537-2554.

Jones, S. 2012. A Tale of Two Cities: Climate Change Policies in Vancouver and Melbourne Barometers of Cooperative Federalism? International Journal of Urban and Regional Research, $36(6), 1242-1267$.

Jones, S. 2013. Climate Change Policies of City Governments in Federal Systems: An Analysis of Vancouver, Melbourne and New York City. Regional Studies, 47(6), 974-992.

Khan, J. 2013. What role for network governance in urban low carbon transitions? Journal of Cleaner Production, 50, 133-139. 
Knuth, S. E. 2010. Addressing place in climate change mitigation: Reducing emissions in a suburban landscape. Applied Geography, 30(4), 518-531.

Laukkonen, J., et al. 2009. Combining climate change adaptation and mitigation measures at the local level. Habitat International, 33(3), 287-292.

Leck, H. and Simon, D. 2013. Fostering Multiscalar Collaboration and Co-operation for Effective Governance of Climate Change Adaptation. Urban Studies, 50(6), 1221-1238.

Li, J. 2011. Decoupling urban transport from GHG emissions in Indian cities-A critical review and perspectives. Energy Policy, 39(6), 3503-3514.

Lundqvist, L. J. and von Borgstede, C. 2008. Whose responsibility? Swedish local decision makers and the scale of climate change abatement. Urban Affairs Review, 43(3), 299-324.

Marsden, G., et al. 2014. Muddling through with climate change targets: a multi-level governance perspective on the transport sector. Climate Policy, 14(5), 617-636.

Marsden, G. and Rye, T. 2010. The governance of transport and climate change. Journal of Transport Geography, 18(6), 669-678.

Martin, N. and Rice, J. 2014. Sustainable Development Pathways: Determining Socially Constructed Visions for Cities. Sustainable Development, 22(6), 391-403.

McGuirk, P., Dowling, R. and Bulkeley, H. 2014. Repositioning urban governments? Energy efficiency and Australia's changing climate and energy governance regimes. Urban Studies, 51(13), 2717-2734. McPhearson, T., et al. 2015. Resilience of and through urban ecosystem services. Ecosystem Services, 12, 152-156.

Monni, S. and Raes, F. 2008. Multilevel climate policy: the case of the European Union, Finland and Helsinki. Environmental Science \& Policy, 11(8), 743-755.

Monstadt, J. 2009. Conceptualizing the political ecology of urban infrastructures: insights from technology and urban studies. Environment and Planning A, 41(8), 1924-1942. 
Moser, C. and Satterthwaite, D. 2010. Toward pro-poor adaptation to climate change in the urban centers of low-and middle-income countries. Social dimensions of climate change: Equity and vulnerability in a warming world, 231-258.

Moser, S. C. 2012. Adaptation, mitigation, and their disharmonious discontents: an essay. Climatic Change, 111(2), 165-175.

Mossberger, K. and Stoker, G. 2001. The Evolution of Urban Regime Theory: The Challenge of Conceptualization. Urban Affairs Review, 36(6), 810-835.

Naustdalslid, J. 2015. Multi-level water governance - the case of the Morsa River Basin in Norway. Journal of Environmental Planning and Management, 58(5), 913-931.

Nevens, F., et al. 2013. Urban Transition Labs: co-creating transformative action for sustainable cities. Journal of Cleaner Production, 50, 111-122.

Newell, P., Pattberg, P. and Schroeder, H., 2012. Multiactor Governance and the Environment. In: Gadgil, A. and Liverman, D. M. eds. Annual Review of Environment and Resources, Vol 37. 365-387. O'Brien, K. L. and Leichenko, R. M. 2000. Double exposure: assessing the impacts of climate change within the context of economic globalization. Global Environmental Change, 10(3), 221-232.

Okereke, C., Bulkeley, H. and Schroeder, H. 2009. Conceptualizing climate governance beyond the international regime. Global Environmental Politics, 9(1), 58-78.

Orleans Reed, S., et al. 2013. "Shared learning" for building urban climate resilience - experiences from Asian cities. Environment and Urbanization, 25(2), 393-412.

Padukone, N. 2012. India's Climate Planning: Environmental Threats, Metropolitanisation and Political Adaptation. South Asian Survey, 19(1), 9-31.

Parnell, S. 2016. Defining a Global Urban Development Agenda. World Development, 78, 529-540. Pasimeni, M. R., et al. 2014. Scales, strategies and actions for effective energy planning: A review. Energy Policy, 65, 165-174. 
Pasquini, L. and Shearing, C. 2014. Municipalities, Politics, and Climate Change: An Example of the Process of Institutionalizing an Environmental Agenda Within Local Government. Journal of Environment \& Development, 23(2), 271-296.

Pearce, G. and Cooper, S. 2011. Sub-national Responses to Climate Change in England: Evidence from Local Area Agreements. Local Government Studies, 37(2), 199-217.

Pelling, M., 2010. Adaptation to climate change: from resilience to transformation. Routledge.

Pelling, M. and Manuel-Navarrete, D. 2011. From resilience to transformation: the adaptive cycle in two Mexican urban centers. Ecology and Society, 16(2), 11.

Pitt, D. and Bassett, E. 2014. Innovation and the Role of Collaborative Planning in Local Clean Energy Policy. Environmental Policy and Governance, 24(6), 377-390.

Pitt, D. and Randolph, J. 2009. Identifying obstacles to community climate protection planning. Environment and Planning C-Government and Policy, 27(5), 841-857.

Radzi, A. 2015. A survey of expert attitudes on understanding and governing energy autonomy at the local level. Wiley Interdisciplinary Reviews-Energy and Environment, 4(5), 397-405.

Revell, K. 2013. Promoting sustainability and pro-environmental behaviour through local government programmes: examples from London, UK. Journal of Integrative Environmental Sciences, 10(3-4), 199-218.

Revi, A., et al. 2014. Towards transformative adaptation in cities: the IPCC's fifth assessment. Environment and Urbanization, 26(1), 11-28.

Rice, J. L. 2010. Climate, Carbon, and Territory: Greenhouse Gas Mitigation in Seattle, Washington. Annals of the Association of American Geographers, 100(4), 929-937.

Rice, J. L. 2014. Public Targets, Private Choices: Urban Climate Governance in the Pacific Northwest. Professional Geographer, 66(2), 333-344. 
Roggema, R. 2014. Dutch and Australian Planning Regimes: Are They Ready to Face Extreme Climate Impacts? European Planning Studies, 22(10), 2067-2093.

Rohracher, H. and Spath, P. 2014. The Interplay of Urban Energy Policy and Socio-technical

Transitions: The Eco-cities of Graz and Freiburg in Retrospect. Urban Studies, 51(7), 1415-1431.

Rosenau, J. N. 2000. Change, complexity, and governance in globalizing space. Debating governance, 167-200.

Roy, A. and Ong, A., 2011. Worlding cities: Asian experiments and the art of being global. John Wiley \& Sons.

Rutherford, J. and Coutard, O. 2014. Urban Energy Transitions: Places, Processes and Politics of Socio-technical Change. Urban Studies, 51(7), 1353-1377.

Sanchez-Rodriguez, R. 2009. Learning to adapt to climate change in urban areas. A review of recent contributions. Current Opinion in Environmental Sustainability, 1(2), 201-206.

Satterthwaite, D., 2007. Adapting to climate change in urban areas: the possibilities and constraints in low-and middle-income nations. lied.

Satterthwaite, D. 2008. Cities' contribution to global warming: notes on the allocation of greenhouse gas emissions. Environment and Urbanization, 20(2), 539-549.

Seeliger, L. and Turok, I. 2014. Averting a downward spiral: building resilience in informal urban settlements through adaptive governance. Environment and Urbanization, 26(1), 184-199.

Seto, K. C., Sánchez-Rodríguez, R. and Fragkias, M. 2010. The new geography of contemporary urbanization and the environment. Annual review of environment and resources, 35, 167-194. Seyfang, G. and Haxeltine, A. 2012. Growing grassroots innovations: exploring the role of community-based initiatives in governing sustainable energy transitions. Environment and Planning C: Government and Policy, 30(3), 381-400. 
Sharifi, A. and Yamagata, Y., 2015. A conceptual framework for assessment of urban energy resilience. In: Yan, J., et al. eds. Clean, Efficient and Affordable Energy for a Sustainable Future. 29042909.

Sharma, D. and Tomar, S. 2010. Mainstreaming climate change adaptation in Indian cities. Environment and Urbanization, 22(2), 451-465.

Shey, J. E. and Belis, D. 2013. Building a municipal food policy regime in Minneapolis: implications for urban climate governance. Environment and Planning C-Government and Policy, 31(5), 893-910. Simatele, D., Binns, T. and Simatele, M. 2012. Urban Livelihoods under a Changing Climate: Perspectives on Urban Agriculture and Planning in Lusaka, Zambia. Journal of Human Development and Capabilities, 13(2), 269-293.

Simon, D. 2008. Urban Environments: Issues on the Peri-Urban Fringe. Annual review of environment and resources, 33(1), 167-185.

Simon, D. and Leck, H. 2015. Understanding climate adaptation and transformation challenges in African cities. Current Opinion in Environmental Sustainability, 13, 109-116.

Simon, G. L., Bumpus, A. G. and Mann, P. 2012. Win-win scenarios at the climate-development interface: Challenges and opportunities for stove replacement programs through carbon finance. Global Environmental Change-Human and Policy Dimensions, 22(1), 275-287.

Smedby, N. and Neij, L. 2013. Experiences in urban governance for sustainability: the Constructive Dialogue in Swedish municipalities. Journal of Cleaner Production, 50, 148-158.

Smit, W. and Parnell, S. 2012. Urban sustainability and human health: an African perspective. Current Opinion in Environmental Sustainability, 4(4), 443-450.

Smith, A. 2007. Emerging in between: The multi-level governance of renewable energy in the English regions. Energy Policy, 35(12), 6266-6280. 
Solecki, W. D. and Leichenko, R. M. 2006. Urbanization and the metropolitan environment - Lessons from New York and Shanghai. Environment, 48(4), 8-23.

Sovacool, B. K. 2011. An international comparison of four polycentric approaches to climate and energy governance. Energy Policy, 39(6), 3832-3844.

Sperling, K., Hvelplund, F. and Mathiesen, B. V. 2011. Centralisation and decentralisation in strategic municipal energy planning in Denmark. Energy Policy, 39(3), 1338-1351.

Stead, D. 2016. Key research themes on governance and sustainable urban mobility. International Journal of Sustainable Transportation, 10(1), 40-48.

Stein, A. and Moser, C. 2014. Asset planning for climate change adaptation: lessons from Cartagena, Colombia. Environment and Urbanization, 0956247813519046.

Storbjork, S. and Hjerpe, M. 2014. "Sometimes Climate Adaptation is Politically Correct": A Case Study of Planners and Politicians Negotiating Climate Adaptation in Waterfront Spatial Planning. European Planning Studies, 22(11), 2268-2286.

Taylor, B. M., et al. 2012. Property Developers and Urban Adaptation: Conceptual and Empirical Perspectives on Governance. Urban Policy and Research, 30(1), 5-24.

Tran Tuan, A., Tran Van Giai, P. and Mulenga, M. 2014. Community consultation for climate resilient housing: A comparative case study in Vietnam. International Journal of Disaster Risk Reduction, 10, 201-212.

UNFCCC, 2013. Report of the Ad Hoc Working Group on the Durban Platform for Enhanced Action on the first and second parts of its second session, held in Bonn from 29 April to 3 May 2013 and from 4 to 13 June 2013. Bonn: UNFCCC/ADPP. van Stigt, R., Driessen, P. P. J. and Spit, T. J. M. 2013. Compact City Development and the Challenge of Environmental Policy Integration: A Multi-Level Governance Perspective. Environmental Policy and Governance, 23(4), 221-233. 
Wamsler, C. 2015. Mainstreaming ecosystem-based adaptation: transformation toward sustainability in urban governance and planning. Ecology and Society, 20(2).

Wamsler, C. and Brink, E. 2014. Moving beyond short-term coping and adaptation. Environment and Urbanization, 26(1), 86-111.

Watson, V. 2013. African urban fantasies: Dreams or nightmares? Environment and Urbanization, 0956247813513705.

Wejs, A. 2014. Integrating climate change into governance at the municipal scale: an institutional perspective on practices in Denmark. Environment and Planning C-Government and Policy, 32(6), 1017-1035.

While, A., Jonas, A. E. G. and Gibbs, D. 2010. From sustainable development to carbon control: ecostate restructuring and the politics of urban and regional development. Transactions of the Institute of British Geographers, 35(1), 76-93.

Zahran, S., et al. 2008. Vulnerability and capacity: explaining local commitment to climate-change policy. Environment and Planning C-Government and Policy, 26(3), 544-562. 